\title{
CASE COMMENTS
}

VEHCLES AND HIGHWAY TRAFIC ACT-STATUTORY LIABIITY OF OWNER-NO DISTINCTION BETWHFN THEFT BY BAIIISE AFTHR ACQUISITION OF VEHICLE WITH OWNER'S CONSENT AND DEVIATION BY BAIEE FROM'OWNER'S INSTRUCTIONS-The decision of the Appellate Division of the Supreme Court of Alberta in Guyton v. Lecroix has extended the liability of an owner of a motor vehicle under section 130 of The Vehicles and Highway Traffic Act ${ }^{2}$ to new heights. This comment is directed to a consideration of the common law position prior to enactment of section 130, the effect of the section, the position in several other provinces, a comparison of their section with section 130 and finally, offering some suggestions for amending section 130.

Lacroix, the owner of the vebicle, was a French Canadian who could not speak or understand English. While in Police Court to face a certain charge he met one Dufour, who, being gifted with a knowledge of French and English and apparently accustomed to the atmosphere of a police courtroom volunteered his services as an interpreter. Lecroix acted upon the advice of Dufour that he plead guilty and thereupon was sentenced to one month's imprisonment. Fe was told by officers of the Royal Canadian Mounted Police, in whose custody he was, that his car could not remain parked on the street, that the police would not move it for him, and that he himself could not do so. To relieve Lacroix from the dilemms, Dufour offered to drive the vehicle the short distance to a garage where the car could be stored. A member of the Royal Canadian Mounted Police prepared a note which was signed by Lacroix authorizing the storage of the car, and then handed the note and the car keys to Dufour. The latter was only given permission to take the car to the garage and was expressly. told he could not use it for any trip on the highway.

Unknown to Lacrolx, Dufour was an ex-convict, wanted in British Columbia for car theft. He promptly stored his own car in the garage and set out for Vancouver to sell Lacroix's car. Fifty miles south of Edmonton he crashed head-on into the plaintiff's car. The rogue Dufour was killed leaving behind no assets, an injured innocent plaintiff and s bewildered car owner.

Guyton, the plaintiff could only succeed against Lacroix by bringing him within section 130 of The Vehicles and Highway Traffic Act, namely:

"130. In an action for the recovery of loss or damages austained by a person by reason of a motor vehiale upon a highway, ... - person who is driving the motor vehicle and who has acquired possestion of it with the consent express or implied, of the owner thereof ahell be deemed to be the agent or servant of the owner of the motor vehicle and to be employed as such, and sholl be deemed to be driving the motor vehicle in the course of his employment, but nothing in 
this section relieves any person deemed to be the agent or servant of the owner and to be driving the motor vehicle in the course of his employment from the liability for the damages."

Counsel for Lacroix contended that Dufour had not acquired the type of possession contemplated by section 130 as Dufour had been guilty of theft by conversion and hence Lacroix ought to be in the same position as if Dufour had stolen the vehicle outright. It was argued that to hold Lacroix liable would be to enlarge the common law liability of the owner of a vehicle to an extent not contemplated in the policy of section 130 as this had been more than a mere deviation from the instructions of the owner. It was also argued that the consent to the acquisition of possession of the car was not the result of the free exercise of the owner's will and that it was not unclouded by fraud or duress. ${ }^{3}$

Chief Justice Smith, delivering the judgment of the Court, said:

"It is my view that by the decisions of this Court. ... the law is settled in Aberta that when the owner expressly consents to another person acquiring possession of his motor vehicle be becomes liable for the nogligence of the driver in the operation of the vehiele notwithstanding that he exceeds any limitation as to use placed upon him by the owner at the time of the acquisition of possession and notwithstanding that the bailee after acquilring possession decides to steal the vehicle and use it entirely for his own purposes. The relevant time for testing whether acquisition of poesession was with the consent of the owner is the time of ruch aequisition. I can soe no difference in prineiple for the purpose of the question under convideration between a deviation by the person in possession from the instructions of the owner and outright thatt of the vohicle by the bollee after he has acquired possession of it with the consent of the owner."

Smith C.J. further felt that it was very clear that Lacroix freely exercised his own will in giving his consent and that no elements of fraud or duress were present.

The effects of this judgment are far-reaching. If $A$ arrives at a downtown hotel, hands over the keys to his car to the porter so that it could be parked in the hotel parking lot, and if the porter converts it to his own use, then, if efforts to recover the car are unsuccessful, $A$ will be liable for any damage caused by the porter's negligent driving even if it occurs years after the keys were handed over. Remarkable as it may seem, that is the settled law of Alberta and perhaps this is one instance where it is better that the law be settled right than merely settled. It appears to be a matter for amending our legislation.

Under the English common law a master is not liable for the negligence of his servant while the latter is engaged in some act beyond the course of his employment though be may be using the instrumentalities furnished by the master to perform his duties as servant." If the servant is on a frolic of his own, without being at all on his master's business, the master will not be liable." But if the servant is doing something pertaining to the course of his employment, the moster will be liable even if at the same time the servant may be carrying out a purpose of his own.'

sBaced on Vaneouver Motora V-Drtie Ltd. V. Walker and Terry, [1942] \&.I.R. 399.

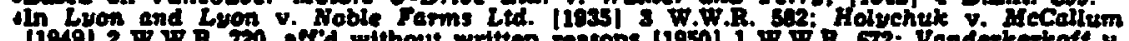

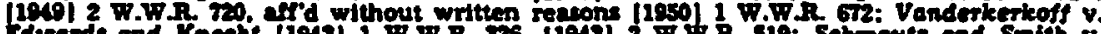

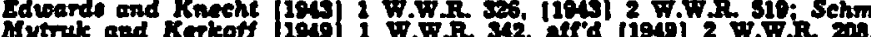

Afalparin $\nabla$. Bullino (1bis) \& W.W.R. os: Storey v. Ahton L.R. 4 Q.B. 476.

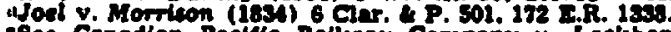

s8oe Canodien Paetfic Rallway Company v. Lockhart [1942] A.C. 501. 
Thus, in Weat and West v. Macdonald's Consolidated Limited and Malcolm, an employee truck driver while on his way to a garage to store a truck after his daily deliveries, proceeded past his girl friend's house 80 that she could accompany him. The employer-owner was held liable for the driver's negligence on this devious route. He was still on his master's business and was not on an independent and separate frolic of his own.

In Halparin v. Bulling, a chauffeur took bis employer's family to the theatre and was to call for them after the performance. His instructions on such occasions were that he was either to take the car back to his employer's garage or to a particular garage in the city. He took the car to the garage in the city but after a few minutes decided to 80 to see a friend before returning to the theatre. While on this side-trip of his own the chauffeur negligently ran into and severely injured a cyclist. The Supreme Court of Canada held that the chauffeur had ceased to be acting in the course of his employment and consequently his employer, the owner of the car, was not liable. Although unanimous in its decision, there was a general feeling of regret which was expressed by Idington J. as follows:

"I regret to be compelled to hold that the common law relative to the ordinary relations of master and servant... under such circumstances, does not enable the courts to do absolute justice ....

Let us hope the law will be changed so far at least that the master who thus Raunts his suppost of such a wrongdoer in the face of one of those he has groealy injured, ahall be made linble for all damagea done by him whilt in such service."10

It took almost twenty years for the Alberta legislature to act in this respect but finally The Vehicles and Highway Traffic Act was amended in 1933 by adding a new section, which is our present section 130. Mr. Justice Ford in Vanderkerkoff v. Edwards and Knecht said regarding this gection: 21

"It is clear that the section is enected to obviate the necessity. of convidering the question which arose in such ceses as Helperin v. Bulling ..."

By virtue of this section not only is the person, who has acquired possession of the vehicle with the consent of the owner, deemed to be the agent or servant of the owner but he is also deemed to be driving in the course of his employment. Commenting on this point Ford J.A. said in the Vandericerkoff case: ${ }^{12}$

"Generally speaking the words "deemed to be" imply an admisajon that the thing spoken of is not that thing or that an act was not is fact done under a given set of circumntances, but that the thing is only for certaln purposes deemed to be that which is not, or that the act is done under circumstanoes which may be non-existent but for certaln puposes are deemed to exist."

Liability of an owner of a motor vehicle was thereby increased. The policy of the section was to give greater protection to the public by warning the owner that he must be careful when entrusting his vehicle to another person to use because if that other person is negligent in using and operating the vehicle then the owner will also be liable for

(193) 2 T.W.A. 657 .

O(2016) 8 W.W.R. 8 .

20lbid. at p. 97.

11[1849] 2 T.T.R. 510 at 529 .

istbid. at 008 . 
the damages. The section was obviously necessary and less than two years after it was enacted it came before the Appellate Division for consideration. ${ }^{33}$

Realizing that section $\mathbf{1 3 0}$ was an extension of common law liability upon the owner judges have paid lip-service to the doctrine that it should not be extended beyond its reasonable implication." But at the same time they felt that the reasonable implication from the terms of the section will never excuse an owner from liability once he has consented to the acquisition of possession by another person, no matter what that person does after such acquisition.

In Lyon and Lyon v. Noble Farms Ltd. ${ }^{23}$ an employee of Noble Farms Ltd. was given permission to use the car on the farm, but he was to leave it at the gate of the farm and not take it on the highway. The employee drove the car on the highway, was in an accident, and the owner was held liable. Speaking for the Court, Lunney J.A. said:

"The important feature to me is that Clifton had the consent of his employer to use the car, to a linited extent it is true, but once such consent has been shown the owner becomes responsible for damages enused by his employee in the operation of the car."10

In Sebzda v. Hupka and Buchkowski, ${ }^{17}$ Hupka, with the express consent of Buchkowski, acquired possession of Buchkowski's truck for the purpose of a visit to the country and to bring back some farm produce. Hupka was to return the truck by noon next day. While at the farm Fupka engaged in a frolic of his own by going to a country dance. When the frolic turned to tragedy and a subsequent law suit, Mr. Justice Boyd McBride held:

"I conceive it to be established law in this Province that, If an owner of a motor vehicle consents to another acquiring possession of it, the owner thereupon incurs and accepts the risk of that other person brealing any promise by him as to tts use or operation or making forbidden use of the vehicle. If injury or damage is suffered by anyone arising in connection with the motor vehide from that other's negligence while it remains in his possession, the owner eannot shield himself behind the other's faithless promises, and theroby eseape linbility. A pledge exacted by the owner liniting the une of the vohicle affords no defence. It matters not that the injury or damages was sustained on a forbldden trlp or in a forbldden area, or while the other was on a frolle of his own. Bo, the owner, having entrusted possewelon of a Jothal weapon' to that other, in low is linble."

It is clear that these cases fall within the policy of section 130, namely, to warn the owner that he had better be very careful to whom he entrusts his vehicle for driving purposes because he will be liable for injuries caused by that person's negligent driving. In both cases the owner was entrusting his vehicle to a person whom he knew and for the express purpose of driving and using it, albeit within limited bounds.

1aLyon and Lyon v. Hoble Farma Ltd. Supre, note 4.

21Degau v. Rremer (1939) I W.T.R. 200, per Harvey CS.A.; Varderkerkoff v. Eduanda and

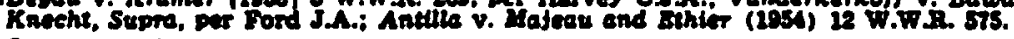

issupre, note 4.

31FFor cases following the Noble Parms care but dealins more partleulnily with tmplied convent cee: Vanderkerkoff v. Edwards and Knecht, Suprai Sehmaute end Smilh v. Mytruk and Kerkoff, Supre. These were cases where in employee had the use of the vohlele day by dey in the cource of his ermployment and on the partleular ocestion took the vehide for pertonal use. The owners were of course held Hible. Althourh $c$.

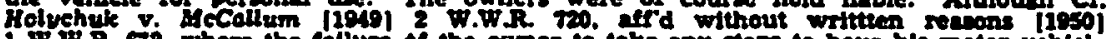
i W.W.R. 672, where the sallure of the owner to tike any stogs to have hls motor vehlcle returned arter the knowlede of a devistion from his instrictlons appess to have been thouthe of Importince.

18|19501 2 W.W.A. 165. 
On the other hand, one cannot help but feel that the owner in Guyton v. Lacroix did not come within the policy of section 130, although admittedly he does fall within the literal wording of the section. There is a big difference between giving your car to another person so that he may use and drive it and giving your car to a person so that it may be placed in storage and not used for driving purposes. It is submitted however, that the finger of criticism should be pointed primarily at the wording of the section rather than at the judgment. The section should be amended to alleviate harsh results.

The wording in the Manitoba statute ${ }^{28}$ is identical with section 130, while in British Columbia'29 the words "or operating" are added after the word "driving", so that the section there says:

"... every person driving or operating a motor vehicle who acquired possession of it with the consent, expreas or implled, of the owner ...."

This section may be somewhat wider than Alberta's by virtue of the words "or operating", since it may well include a person who was not driving but still primarily in charge of the operation of the car. In Degau v. Kramer," an Alberta case, it was beld that the words "person driving" do not include any person other than the person physically in charge of the mechanical devices which control the car.

The leading case from British Columbia on this section is Vancouver Motors U-Drive Ltd. v. Walker and Terry. ${ }^{22}$ It was relied on by counsel for Lecroix to support the argument that the consent was not the result of the free exercise of the owner's will but was prompted by the strange and impelling circumstances. However, the majority of the Supreme Court of Canada in the Vancouver Motors case and the Appellate Division of Alberta in Guyton.v. Lacroix both held that if the owner of bis own volition hands the keys of his car to a rogue thinking him to be an honest friend in need, he cannot escape liability with the plea that his consent was not real when the true features of the rogue are exposed. ${ }^{23}$

If section 130 is to be amended, it is submitted that no help can be derived from elther the Manitoba or British Columbia sections.

The Vehicles Act of Saskatchewan provides: "a

"... and the owner thereof shall also be liable to the same extent as the driver unicas at the time of the Incldent causing the loss, damage or injury the motor vohicle had been stolen from the owner or otherwise wrongfully taken out of his possession or out of the possevion of any person entrusted by him with the care thereof."

It is clear from the above wording that had Guyton v. Lacroir oceurred in Saskatchewan there would have been no liability on the part of the owner. The relevant time in Saskatchewan for testing the owner's consent is not the time of acquisition of possession but the time of the incident causing the loss, damage or injury. Thus a person may have

taRsM. 1954, c. 122 . $95(9)$

10Rs. B.c. 1060, e. 250 , o ro(i).

cosupra, note 14

stsupin, note 3 .

efrucheresu J. dirented in the supreme Court of Canada, seolling that the word "eonsent" should have the cane meanins as in other lear contexts and that therefore there is no

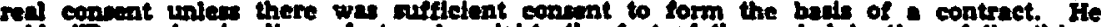

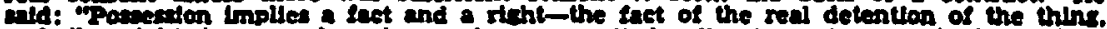

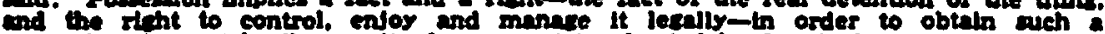
posmaton. It mut be the reall of a consent unclouded by fraud. dures, or somethmes wen mirtake.".".

231097 (Baste) c. 98. 1. $167(1)$. 
acquired possession with the express consent of the owner but such rightful possession may turn into wrongful possession, by theft or otherwise, and if the injury takes place at a time when the driver was in wrongful possession, then the owner will not be liable.

In Marsh v. Kulchar, 24 the Supreme Court of Canada had to consider the Saskatchewan section. In that case the owner entrusted his truck to his wife for a trip in which she was accompanied by their farm-hand. At the destination she left the key in the ignition and told the farm-hand to look after the truck so no children could touch it. The farm-hand drove the truck a short distance to a coffee shop so that he could "look after it". It was held that such was wrongful taking out of possession within the meaning of the Act and therefore the owner was not liable for an accident near the coffee shop.

It is submitted that section 130 should be amended to incorporate the provisions of s. 157 (1) of the Saskatchewan Act insofar as theft or otherwise wrongfully taking out of the owner's possession is concerned. Such amendment would still preserve the policy of the Act but the undue hardship presently placed upon owners in Alberta would be eased.

In Ontario the Highroay Traffic Act ${ }^{23}$ provides:

"The owner of a motor vehicle shall be liable for loss or damage sustained by any pereon by reeson of negligence in the operation of the motor vehicle on a highway unless the motor vahicle was without the owner's consent in the posseasion of some person other than the owner or his chauffeur ..."

It is interesting to compare the interpretation of this section by the Ontario courts with that of the Alberta courts in regard to section 130. The major difference between the two sections is that section 130 deals with a person who "has acquired possession" and the Ontatrio section deals with a person who "was ... in the possession" of the vehicle without the consent of the owner.

In the Ontario case of Newman and Newman v. Terdik, 28 an owner gave consent to his employee to use the automobile for the purpose of shuttling back and forth between two kilns on a tobacco field but was expressly told he could not use it on the highway. Mr. Justice Mackay of the Ontario Court of Appeal held the owner not liable for an accident on the highway caused by the employee's negligence. He said:

"S. 50 (now s. 105) deals only with liability for damages ariaing by zeason of the neglisent operation of a motor vehicle on a highwey. Used in this context the words "without the owner's consent in the possession of some person other than the owner or his chouffeur" can only be rofernble to possession on a highwry. I think it clear. .. that possession can change from rightful possession to wrongful possescion, or from possession with consent to possession without consent, without any change in the actual physical possoasion of the chattel."12

Chief Justice Smith in Guyton v. Lacroix was of the opinion that section 130 was not a parallel at all to Ontario's section 50. If he was referring to the distinction between "acquired possession" in the Alberta statute and being "in the possession" as in the Ontario act, then his opinion may be justified, but if he was referring to the interpretation of Mackay J.A. that consent "can only be referable to possegsion on a highway" because "section 50 deals only with liability for damages

21129831 I S.C.R. 380.

20A.5.0. I060, e. 172, a. $105(1)$.

201105s)o. R. 1 .

iftbid. at 8.7 . 
arising by reason of the negligent operation of a motor car on a highway", then Smith C.J.'s opinion is not so sound. For it is noted that both the Alberta and the Ontario sections equally refer to llability arising for loss or damage sustained by a person by reason of a motor vehicle upon a highway. Thus, without more, the interpretation placed upon section 50 by Mackay J.A. could equally apply to the Alberta section. But while MacKay J.A. felt these words infer that consent must consequently refer to possession on a highway, the Alberta Appellate Division in the Noble Farms case held to the contrary:

"In order to give effect to this argument it would be necessary to read into the section "for use upon the highway" or words of simllar import, so that the section would be to the effect; Every person driving such motor vehicle who has acquired posecssion of th, for use upon the highway, with the consent, express or implied, of the owner." "ro (Italles supplied)

It is therefore arguable that in Ontario, the owner Lacroix would not have been liable. This argument is supported by LeBar v. Barber and Clarke 29 where Clarke the owner, delivered his car into Barber's hands. Barber was a garageman and was to do work on the car which would immobilize the car while at the garage. Barber however, took it out on the highway without Clarke's consent and was in an accident due to his negligence. Clarke was held not liable. In the Ontario Court of Appeal Fodgins J.A. said:

WEere it is not merely exeess or disobedlence but the wholly different and wronglul mothod of treatinent and user. If the owner had entrunted his enr to another to use on the hiphway, or to drive if to any stipulated place or within certin limits then I think the statute would apply notwithotanding the restriction. But this would be beenuse use was permitted and intended and posecsion wes given for use and not for storage or other purposes, and it was in that areed use that the demage cocurred. Eere no user of the ent was intended or implied."

In Alberta Clarke would clearly have been liable because possession was acquired by express consent of the owner and no regard is given to the purpose for which the possession was given.

In Newfoundland the corresponding section also uses the expression "ualess such motor vehicle was without the owner's consent in the possession of some person . . ." It was recently considered by Dunfield J. in Porter v. Terre Nova Motors Ltd." His conclusion even after considering the Alberta cases prior to Guyton v. Lavroir, was:

Whe reneral view in selntion to this type of section seems to be that if an employee does damage while using a vehicle for purpose for which he had no permitaion at ell, then the employer is not liable, but if as in the ease now before us, there he been pexmission to drive on the highway, a reasonable excess or disobedience by the driver in reppect of that anme use does not free the carowner of liability; which after all, ... i in in eccordance with common sense, as happlly the low so often is."ms (Itrilics aupplied)

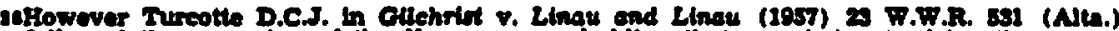
tollowed the reseonline of the Newman eace holdine that pormition to drive the ent on the tarm did not fve pasecedon of the car with the ovner's "consent express or implled" wthth the meanth of a. 130 when drivtns it on the hishwar at the thine of the rectient.

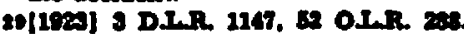

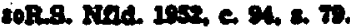

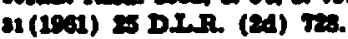

arthe fact wers that Jonew, anc-armed war veteran, went to Totra Nove Motors to

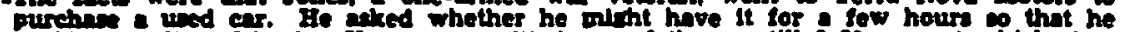
could chow it to ertends. He wes permitted we of the ent ull 9:30 p.m. at which ume he was to retum and complete the purchase ascement. Jones, nevor intendins to buy Jt. dld not retum and at 10:00 p.m. wes in an aecident. The ownere were held liable. 
The same cannot be said for section 130 of the. Alberta act, the effect of which is to stretch common sense to absurdity by making an owner liable even when his car has been stolen from him by a professional car-thief once possession was acquired by the owner's consent.

It is submitted that the soot of the trouble goes right to the words "has acquired". Once they appear in the section there can be little quarrel with the statement of Smith $C . J$. that:

"The relovant time for testing whether acquisition of possession was with the consent of the owner is the time of such acquisition."

In the case of theft by conversion or otherwise wrongfully taking the vehicle out of the owner's possession, section 130 goes far beyond the original policy of the statute and places an undue burden and risk of liability upon owners of automobiles. The section should be amended either (a) along the lines of the Saskatchewan act which excludes an owner from liability if his car has been stolen or wrongfully taken out of his possession, even though possession may have originally been acquired with the owner's consent; or (b) at least similar to the Ontario and Newfoundland sections, by striking out the words "has acquired" and putting in their place the words "is in" immediately preceding the word "possession". This would make the relevant time for testing the owner's consent the time of the accident causing the damage and not the time of the original acquisition. Provision would thus be made for possession to change from rightful to wrongful and the car owner would be exonerated in the latter case.

WAITER SHANDRO 